\title{
MANAGEMENT OF JOINT-STOCK COMPANIES AND FARMS BY USING FAIR VALUE OF AGRICULTURAL EQUIPMENT IN FINANCIAL STATEMENTS ON THE EXAMPLE OF IMT 533 TRACTOR
}

\author{
Milan Radovićl , Jelena Vitomir ${ }^{2}$, Bogdan Laban ${ }^{3}$, Slobodanka Jovin ${ }^{4}$, Sanda Nastić, \\ Vera Popović ${ }^{\text {, Slobodan Popović }}{ }^{7}$, \\ *Corresponding author E-mail: slobodan.popovic49@gmail.com
}

\begin{abstract}
A R T I C LE IN F O
Original Article

Received: 13 February 2019

Accepted: 11 March 2019

doi:10.5937/ekoPolj1901035R

UDC 347.728 .1

Keywords:

fair value, agricultural machinery, tractors, financial report

JEL: M41, G32, H39

\section{A B S T R A C T}

More demanding management requires management to foster the application of different mechanisms. One of the upcoming ways of improving management is the use of the fair value of property and equipment in the business books of the company. The authors of this study emphasize the importance of fair valuation of agricultural equipment, processing surveyed 382 legal entities of the Republic of Serbia, in the case of widespread tractor IMT 533 agricultural holdings in 207 and 175 joint-stock companies. To show the real application of fair value, the research period lasted from 2015 to 2018 . We came to the basic conclusion that there is a statistically significant relationship between organizations, enterprises and the age of the tractor to the application of the fair value of the tractor in the business books of the company. There is also a conclusion that fair financial reporting brings about benefits to agricultural entities of other legal forms.
\end{abstract}

(C) 2019 EA. All rights reserved.

1 Milan Radović, PhD, Faculty of Economics Pale, University of East Sarajevo, Alekse Šantića 3, 71420 Pale, Bosnia and Herzegovina, +387 57 226-651, knowledgemilan@ gmail.com ORCID ID https://orcid.org/0000-0002-0751-2522

2 Jelena Vitomir, PhD, jelena.vitomir1@gmail.com, ORCID ID https://orcid.org/0000-00016995-3297

3 Bogdan Laban PhD, City administration of the City Subotica, Trg Slobode 1, 24000 Subotica, Serbia +381 +381 24626 888, bogdanl.su@gmail.com, ORCID ID (https:// qa.orcid.org/0000-0002-3730-0125

4 Slobodanka Jovin PhD, Professional Studies, High Business School of Novi Sad, Vladimira Perica Valtera 4, Serbia, boba_jovin@yahoo.com, ORCID ID https:/qa.orcid.org/00000003-4312-4532

5 Sanda Nastic, PhD, JKP Vodovod i kanalizacija, Novi Sad, Masarikova 17, 21000 Novi Sad, Serbia, +381021 4888 3333, sanda.nastic@vikns.rs, ORCID ID https://qa.orcid.org/00000002-9500-6629

6 Vera Popovic, PhD, Institute of Field and Vegetable Crops, Maksim Gorkog, 30, Novi Sad, Serbia, vera.popovic@ifvens.ns.ac.rs, ORCID ID https://qa.orcid.org/0000-0001-6032-6457

7 Slobodan Popovic, PhD, Faculty of Economics and Engineering Management, Cvecarska 2, Novi Sad, Serbia, Phone: +381 640483 563, slobodan.popovic49@gmai.com, ORCID ID https:/qa.orcid.org/0000-0002-7884-2051

http://ea.bg.ac.rs 


\section{Introduction}

This work aims to provide valid evidence on the importance of using the fair value of the tractor in the business books of the company. It dominantly refers to the observation of agricultural holdings and joint stock companies in countries that want to join the EU, such as the Republic of Serbia. For the emergence of this work we used the views of the author, which originate from EU (Argilés \& Slof 2001; Barlev \& Haddad 2003; Feleagă at al. 2012), associated with the standardization of accounting observation and fair valuation.

During the last about 10 years it can be seen growing interest of a large number of authors who have pointed to possible improvements of the companies' management through the application of enhancements of top management financial reporting (Popović and al. 2015; Novaković and al. 2018; Popović and al. 2018). So conceived management requires from the companies' financial sector the full implementation of the already adopted international accounting standards (Daske at al. 2008; Cai and Wong, 2010). The application of international accounting standards directs small (such as farms) or large legal entities (egg. joint stock companies) to support the introduction of fair value of all assets held by the business books (Popović and al. 2014a).

Despite its commitment to democratic values, the European Union does not permit a full range of legitimate democratic choice in the economic sphere (Smith \& Weeks, 2018) Presentation of fair value of equipment can be a consequence of management decisions based on recommendations of the internal control. (Arena et al. 2006; Endaya \& Hanefah 2013). There are similar positions both among authors from developing countries and those from developed EU countries (Cantino, 2009; Catuogno et al. 2016). Such views of fair valuation enhance certainty of management (Greuning, 2006; Durocher \& Gendron 2014; Funnell et al. 2016), but it should be noted that the role of actual accounting department of an enterprise should not be neglected (Barker \& McGeachin 2013). Besides, International Accounting Standards and other financial reporting standards have to be adhered to (Brousseau et al. 2014), as it affects the appropriate presentation of operating results (Brown and Szimayer 2008).

The effects of fair valuation (Guthrie et al. 2011; Christensen et al. 2012) are created with the application of fair reporting, which is enabled by the financial reporting standards or in other words, the mentioned activities as a whole enable greater preciseness and certainty in management.

Numerous authors in different ways refer the professional public to the importance of corporate governance (Nowak and al., 2016; Baráth \& Fertő 2017; Kijek et al., 2019; Gaetano \& Lamonaca, 2019; Lee, 2019; Rodriguez and al., 2019) in the domain of organizing very heterogeneous agricultural activities (Anwar \& Sun, 2015; Boukalova et al., 2016; Dax \& Oedl-Wieser, 2016; Kuo et al., 2018; Wang., 2019).

The study conducted has a multidisciplinary approach. It brings into relation the economic-agrarian idea of agricultural equipment of agricultural estates and joint-stock 
companies with an aim of their attitude toward fair valuation of agricultural equipment. In this study, the equipment is viewed through the selected IMT 533 tractors, of different year of make, that are at disposal of and managed by joint-stock companies and farms in the course of their ordinary operations.

\section{Material and methods}

The analytical framework is based on an assumption of application of as realistic as possible financial reporting which is in the subsequent stage a basis for making valid business and management decisions. Initiating new decision making relating to financial reporting according to Arena \& Azzone (2007), could be a consequence internal controls of an enterprise.

Besides, when decisions on financial reporting, altering financial statements etc. are made, the very changes in the accounts are, according to Florou et al. (2016) linked to enterprise accounting department.

Having in mind all stated in this paper, the success of management is, among other things, reflected through a fair valuation of agricultural equipment. The author assumed the application of a methodological approach which is common in social research. Although the study is basically a comparative analysis, in its narrowest sense there is a case study which is observed, i.e. the selected individual agricultural equipment, the IMT 533 tractor, is in the focus of the research.

A comparative analysis is used to present the assumed differences in the use of fairvalue reporting in joint-stock companies and farms in the Republic of Serbia. On the basis of that, a universal nature of views resulting from the analysis of the obtained results of the study can be pointed out.

\section{Methods and current research}

The authors used survey as a research method in order to get reliable information which could assist in the description of the process of fair valuation of agricultural equipment comprising 382 legal entities in the Republic of Serbia. In this paper, the authors by the questionnaire came to the relevant information concerning the business of agricultural holdings and joint stock companies in the Republic of Serbia, when it comes to the application of the fair value of the tractor in the business books the respective legal entities. The specific questions were set to managers and owners of farms, whether they apply IAS 16, or whether they carry out a reappraisal of the value of equipment every three years (tractors) which they use or not. The time interval of observation covered the period from 01.01.2015 to 30.06.2018. The aim of the survey was to acquire reliable information regarding the fair value of the practical application of agricultural equipment i.e. IMT 533.

The presented results in this paper are based on data processing 382 surveyed legal entities, which dominantly operate in the Republic of Serbia in the field of agriculture, 
of which 175 surveyed are joint stock companies and 207 agricultural holdings. All obtained information originates from top management and owners of agricultural holdings. The authors point out that the information is obtained in the survey, and from the responsible person, which the authors considered relevant.

The authors' basic assumption is that expression of the fair value of the tractor in the business books can have benefits for all people in management functions in the Republic of Serbia. The authors' first step after the results of the survey was data processing, with a view to classification of respondents into two groups: the group of farms and the group of joint stock companies. The aim of the aforementioned steps was to detect possibly different behavior of joint stock companies and farms regarding the introduction of fair value of the tractor in the business books respective legal entities. In addition, the authors observed the behavior of enterprises in the agricultural sector in longer period, especially focused on behavior of companies when it comes to expression of fair value of the equipment or the tractors in the business books.

In the second step, the researchers examined whether there is a connection between the ages of tractors and introducing fair valuation of tractors in the business books of the aforementioned groups of legal entities. They observed a model of the tractor which was being produced in the former Yugoslavia; in fact it is a tractor IMT 533. The aforementioned tractor was produced from mid-50s to the 2005. During that period, about 800,000 tractors of this type were produced. The interesting fact is that a large number of tractors remained in use until 2016. The oldest tractor, which was in use and which was covered by a fair evaluation of this paper was made in 1959, and the youngest was produced in 2005. Therefore mentioned tractor model was in use about 46 years. The authors observed the total interval age of tractors in use, and divided it into five observation period, as follows: 1955-1965; 1965-1975; 1975-1985; 1985 1995 and 1995-2005, in order to discover similarities evaluating individual interval covered by the entire period.

In the third step, the authors processed the obtained results in order to establish the existence of a statistically significant relationship between stock companies and farms as the owner of a tractor, in terms of the application of the fair value of the tractor in the accounts. Chi-square test was used for research (Turjacanin and Cekrlija 2006). Also it is required the connection between the ages of tractors and application of the fair value of the same in the business books of the surveyed companies.

In part four of the study it was examined if there were differences in the proportion of the sample of enterprises applying the fair value principle on the basis of measurements that were made four times, in 2015, 2016, 2017 and 2018, the years in which the research was conducted. Thus, measurements were repeated in order to support views relating to establishing tested differences among three or more matched sets of frequencies. A quantitative variable was in the focus, i.e. the focus of the study was on the application of fair valuation of agricultural equipment (tractors) in the financial records. 


\section{Hypotheses}

Having in mind their conceptual framework, characteristics of joint-stock companies and farms with regard to the application of fair valuation of agricultural equipment and expected effects on the basis of literature and intuitive expectations of the authors, are formulated in 4 hypotheses.

Hypothesis 1 (H1): Fair reporting, predominantly on enterprise equipment, gives enough freedom to make valid managerial decisions as pointed out by authors like Williams (2010). Taking into account the above stated, a starting point is that there is no statistically significant relationship between ownership structure of a farm and presentation of fair value in the books.

Hypothesis 2 (H2): The quality of enterprise management implies (Popović, 2014) a comprehensive treatment of a great number of management segments, an important part of which relates to fair valuation of equipment. Such approach is pointed out by other authors as well, like Soltani (2009). Having that in mind, the authors believe it is necessary to examine the statistical significance of relationship between joint-stock companies and farms and the application of fair valuation of agricultural equipment.

Hypothesis 3 (H3): Dynamics in the treatment of enterprise management is a basis of a modern approach to enterprise development, which is pointed out by many authors, like. With regard to that, a point of departure is that there is a difference in the proportion of the sample of agricultural enterprises applying fair valuation in their operations in all observed points of time (years that are observed). Thereby a dynamic aspect in dealing with heterogeneous agricultural enterprises is observed.

Hypothesis 4 (H4): Further observation of social valuation is pointed by many authors, like Bozzolan and al. (2014), Bratten and al. (2016) which is accepted by the authors of the study. At the same time, a scope of observation is widened in at least one point (year under observation) when fair valuation in agricultural enterprises substantially different in the form of ownership is concerned.

\section{Statistical analyses}

The obtained data of the survey conducted on a representative number of randomly selected respondents that represent joint-stock companies and farming estates in the Republic of Serbia relate to the application of fair valuation of agricultural equipment. In the analysis, the statistical package SPSS for Windows, version 17.0 was used. Two tests were made. The first, Chi-square test, was used with an aim of determining a significant relationship between the form of organization applying fair valuation and the age of agricultural equipment in 2017 and 2018. The second, Cochran's Q Test, was used in order to determine differences in the proportion of enterprise sample measured in four time points: 2015, 2016, 2017 and 2018, i.e. in four years. 


\section{Results}

The authors presented the results of the research in three parts after reviewing. An overall view of results related to the period 2015-2018 is given in the first part, regarding the application of the fair value of the tractor IMT 533 of 382 interviewed entities. In table 1 the authors show the number of companies that have applied the fair value of the tractor in the business books per years of observation. In addition, for comparison of possible relationships and trends, the authors give the show of percent in relation to any form of mentioned economic organization, but only to those that applied the fair value of the tractor in their business books.

Table 1. Overview of the number of legal entities and the percentage of companies that applied the fair value of the tractor, per years of observation

\begin{tabular}{|l|c|c|c|c|c|c|c|c|}
\hline \multirow{2}{*}{$\begin{array}{l}\text { The form of the } \\
\text { company }\end{array}$} & \multicolumn{9}{|c|}{ Year of observation } \\
\cline { 2 - 9 } & \multicolumn{2}{|c|}{$\mathbf{2 0 1 5}$} & \multicolumn{2}{|c|}{$\mathbf{2 0 1 6}$} & \multicolumn{2}{c|}{$\mathbf{2 0 1 7}$} & \multicolumn{2}{c|}{$\mathbf{2 0 1 8}$} \\
\cline { 2 - 9 } & $\mathrm{A}$ & $\mathrm{B}$ & $\mathrm{A}$ & $\mathrm{B}$ & $\mathrm{A}$ & $\mathrm{B}$ & $\mathrm{A}$ & $\mathrm{B}$ \\
\hline $\begin{array}{l}\text { Joint stock } \\
\text { companies }\end{array}$ & 8 & 4.57 & 20 & 11.42 & 45 & 25.71 & 80 & 45.71 \\
\hline $\begin{array}{l}\text { Agricultural } \\
\text { holdings }\end{array}$ & 2 & 0.97 & 4 & 1.93 & 14 & 6.76 & 60 & 28.98 \\
\hline In total & 10 & 2.67 & 24 & 6.98 & 59 & 15.45 & 140 & 36.64 \\
\hline
\end{tabular}

Note $(\mathrm{A}=$ the number of legal entities; $\mathrm{B}=$ percentage of the total number of the shape of the economic activities of legal entities)

\section{Source: Research results (2018)}

After the presentation of the results in Table 1, in the second part of the analysis of the results of the surveyed legal entities, the authors give a review of the last year of observation, respectively in 2017 and 2018. This focuses on the developments in the aforementioned years, when positive progress was made in the practical benefit of application of the fair value of the tractor in the business books of the surveyed legal entities.

In addition, all tractors which are fair valued are covered by age, or by year of production. Due to the great length of the interval it is divided into five observation intervals: 1955$1965 ; 1965-1975 ; 1975-1985 ; 1985-1995$ and $1995-2005$. The fair value of the tractors was observed in the business books of the mentioned legal entities in 2017 and 2018.

For possible comparisons it is also presented the number of enterprises or agricultural farms which are applying fair valuation, but it is also given the show of the number of those legal entities that do not apply fair reporting in the business books. Below is the percentage ratio under each of the five observation period, the total carrying amount by intervals, and the total value of the application, i.e. non application of the fair value of the tractor. Display by age groups of the tractor and apply fair valuation for 2017 is given in Table 2. 
Table 2. Display by age groups of the tractors and application of evaluation for 2015.

\begin{tabular}{|c|c|c|c|c|c|c|}
\hline $\begin{array}{l}\text { Age tractors } \\
\text { observed at } \\
\text { intervals within the } \\
\text { year }\end{array}$ & $\begin{array}{c}\text { Do not apply the principle } \\
\text { of fair value }\end{array}$ & $\begin{array}{c}\text { Apply the principle of } \\
\text { fair value }\end{array}$ & \multicolumn{2}{|c|}{ In total } \\
\cline { 2 - 7 } & $\mathrm{f}$ & $\%$ & $\mathrm{f}$ & $\%$ & $\mathrm{f}$ & $\%$ \\
\hline $1955-1965$ & 8 & 88.9 & 1 & 11.1 & 9 & 100 \\
\hline $1965-1975$ & 11 & 55.0 & 9 & 45.0 & 20 & 100 \\
\hline $1975-1985$ & 202 & 89.4 & 24 & 10.6 & 226 & 100 \\
\hline $1985-1995$ & 51 & 67.1 & 25 & 32.9 & 76 & 100 \\
\hline $1995-2005$ & 51 & 100 & 0 & 0 & 51 & 100 \\
\hline In total & 323 & 84.6 & 59 & 15.4 & 382 & 100 \\
\hline
\end{tabular}

Source: Research results (2018)

Continuation of the research was done for 2018, and display of division into age groups of the tractors and application of evaluation can be seen in Table 3.

Table 3. Display by age groups of the tractors and the application of fair valuation for 2016

\begin{tabular}{|l|c|c|c|c|c|c|}
\hline $\begin{array}{l}\text { Age tractors } \\
\text { observed } \\
\text { at intervals } \\
\text { within the } \\
\text { year }\end{array}$ & $\begin{array}{l}\text { Do not apply the principle } \\
\text { of fair value }\end{array}$ & f & \multicolumn{2}{|l|}{$\begin{array}{l}\text { Apply the principle of fair } \\
\text { value }\end{array}$} & \multicolumn{3}{|c|}{ In total } \\
\cline { 2 - 7 } & $\%$ & f & $\%$ & f & $\%$ \\
\hline $1955-1965$ & 8 & 88.9 & 1 & 11.1 & 9 & 100 \\
\hline $1965-1975$ & 12 & 60 & 8 & 40 & 20 & 100 \\
\hline $1975-1985$ & 195 & 86.3 & 31 & 13.7 & 226 & 100 \\
\hline $1985-1995$ & 27 & 35.5 & 49 & 64.5 & 76 & 100 \\
\hline $1995-2005$ & 0 & 0 & 51 & 100 & 51 & 100 \\
\hline In total & 242 & 63.4 & 140 & 36.6 & 382 & 100 \\
\hline
\end{tabular}

Source: Research results (2018)

The third part of the research is a continuation of the analysis of the last two years in connection with the application of the fair value of tractors in Serbia. This leads to reliable information about the existence of a statistically significant link between joint stock companies and farms as the owner of a tractor, and the application of fair value in the business books of the respective legal entities. The authors also tried to establish a link between the age of tractors that the company owns and application of fair valuation. This was done by using the Chi-square test. 
Chi-square test was used, to test the existence of relations between the two categorical variables that should be compared with the proportion of cases in each category, with the values that would be expected, that between those two observed variable there is no connection. The analysis was carried out processing information obtained by the survey for 2017 and 2018, as in previous years negligibly small number of companies applied the principle of fair valuation, which is emphasized in the previous paragraphs of the authors.

In this paper the variables were analyzed in order to identify:

- Links between forms of organization (joint stock companies and farms) on the one hand and their application of fair valuation of tractor IMT 533 in the business books of the respective legal entities in the Republic of Serbia on the other hand

- $\quad$ Links between the the age of tractors that mentioned legal entities possess and their application of the fair value in the business books of the same.

The research results. after processing using the Chi-square test with the aim of existence of links between selected variables, are shown in table 4.

Table 4. Display of the application of the fair value of the results obtained after the Chi-square test for the 2017 and 2018

\begin{tabular}{|l|c|c|c|c|c|c|}
\hline \multirow{2}{*}{$\begin{array}{l}\text { We analyzed } \\
\text { categorical variables }\end{array}$} & \multicolumn{5}{|c|}{ Year of observation } \\
\cline { 2 - 7 } & \multicolumn{3}{|c|}{2017} & \multicolumn{3}{c|}{2018} \\
\cline { 2 - 7 } & Winning values & $\mathrm{c}$ & Chi-square & $\mathrm{df}$ & $\mathrm{p}$ \\
\cline { 2 - 7 } $\begin{array}{l}\text { Total number of } \\
\text { analyzed agricultural } \\
\text { enterprises } \\
\text { (N = 382) }\end{array}$ & 26.078 & 1 & 0.000 & 11.430 & 1 & 0.001 \\
\hline Age tractor & 44.572 & 4 & 0.000 & 167.315 & 4 & 0.000 \\
\hline
\end{tabular}

Source: Research results (2018)

The results of Chi-square test shows that there is a statistically significant link between the forms of organization, or joint stock companies and farms and their application of fair value in their books, as well as between the age of the tractors and their application of fair value in 2017 and 2018. The obtained results presented in Table 4 indicate that the resulting value is $\mathrm{p}<0.05$, which means that the authors with the $95 \%$ confidence claim that the tested connections are statistically significant and the null hypothesis is rejected in favor of the alternative hypothesis.

The fourth part of research results is further in favors of the fair valuation hypothesis in the course of ordinary operations of agricultural enterprises. To arrive to that, it was 
necessary to examine the existence of differences in the proportion of the sample of agricultural enterprises applying the principle of fair valuation in their operations in all points of time (years under observation), as comes out from the hypothesis. An even deeper observation of views on the existence of difference even in one point (year of observation) regarding fair valuation in agricultural enterprises is the last phase of the statements given in hypothesis 4 at the beginning of the paper.

In order to prove statements, the Cochran's Q Test (Bagdonavicius \& Nikulin 2011) were used as it enables repeated measurements aimed at discovering possible differences in the proportion of the sample of enterprises applying the fair valuation principle measured in four points of time: 2015, 2016, 2017 and 2018 (which are actually the years in which the research was made).

The obtained results are presented by the authors in Tables 5 and 6. Please note that the application or non-application of fair valuation of agricultural equipment in enterprise financial records is presented for the years in question.

Table 5. Frequency display (years) and the application of the fair value of agricultural equipment

\begin{tabular}{|c|c|c|c|c|}
\hline \multirow{2}{*}{$\begin{array}{l}\text { Year of } \\
\text { observation }\end{array}$} & \multicolumn{2}{|c|}{$\begin{array}{c}\text { Do not apply the principle } \\
\text { of } \\
\text { fair value }\end{array}$} & \multicolumn{2}{c|}{$\begin{array}{c}\text { Apply the principle } \\
\text { of } \\
\text { fair value }\end{array}$} \\
\cline { 2 - 5 } & Number & $\%$ & Number & $\%$ \\
\hline 2015 & 372 & 97.4 & 10 & 2.6 \\
\hline 2016 & 358 & 93.7 & 24 & 6.3 \\
\hline 2017 & 323 & 84.6 & 59 & 15.4 \\
\hline 2018 & 242 & 63.4 & 140 & 36.6 \\
\hline
\end{tabular}

Source: authors' calculation

Table 6 shows the results following the testing.

Table 6. Display test results (Cochran's Q Test)

\begin{tabular}{|c|c|}
\hline Description & Received values \\
\hline sample size & 382 \\
\hline Cochran's Q Test & 283.57 \\
\hline $\mathrm{df}$ & 3 \\
\hline $\mathrm{p}$ & 0.000 \\
\hline
\end{tabular}

Source: authors' calculation

The result obtained is statistically significant. It can be seen that there are significant changes in percentage of enterprises applying the fair valuation principle in the given points of time. In the first observed year (2015), the number of enterprises which applied 
fair valuation of agricultural equipment expressed as percentage was only 2.6 out of 382 enterprises covered by the survey. In each subsequent year the number increased by more than twice, and in 2018 the percentage of enterprises applying fair valuation in their ordinary activities was 36.6 .

\section{Discussion}

The presented results can serve as a basis for obtaining an overall picture when it comes to the application of the fair value of the tractosr in the period 2015-2018 in the Republic of Serbia. The first point, to which the authors indicate arises from the tabulation 1, is the conclusion that there are positive movements in relation with the introduction of the fair value of the tractors in the business books. Joint stock companies by the end of 2015 had $4.6 \%$ of subjects who introduced fair value in their business, and by the next year, that percentage increased and amounted to just over $11 \%$, and in mid-2018, the percentage was about $45 \%$. In the same period it can be seen that the farms at the beginning of the observation period had four times worse starting position in relation to the joint stock companies. At the end of the observation period, this percentage was fixed, and an increase in the number of those farms that apply the fair value can be seen, and at the end of the observation period it amounted to almost $30 \%$ of surveyed farms.

Another point that was emphasized in this paper refers to 2017, where the authors analyzed the age of the tractors, and how it reflected on the presentation of the fair value of the tractors. Namely, in the oldest period (1955-1965) of observation of tractors by year of production, there is also the smallest number of tractors (Table 2), which was expected. The results indicate that the fair valuation is about $11 \%$ of all tractors in this interval. We emphasize that these are very old tractors, age over 50 years, but is still used within the business of enterprise and they need to be evaluated in the the business books which is in accordance with the paragraph, that the management of enterprises must continuously improve. Authors observed the fair value in the context of improving the management, because then the value of the assets, ie equipment is approaching to the market value, which is in accordance with IAS 16. In the interval 1965-1975 the precent of number of the fair valued tractors is the highest and it is $45 \%$ compared to the observed tractors in that interval. It should be noted that the number of individual tractors that are fair valued is not the greatest. In the next interval (1975-1985) the number of tractors that are fair valued grows at 24 , although the percentage of valued tractors in this way is $10 \%$ in this interval. In the interval of observation (1985-1995) almost the same number of tractors that are fair valued was kept and it accounted for 25, although in this interval the percentage of fair valued tractor is growing to about $30 \%$. The last observation interval by the age of tractors is (1995-2005) and we can see that in both forms of economic organization for 2017 there are no tractors that are fair valued.

The third point relates to the last year of studies, ie 2018, when it comes to the fair value of tractors in relation to the five preset interval, in which the company tractors are classified according to the criteria of age. Based on the display given in Table 3 it can be seen that in the first interval of observation ie in the period (1955-1965), the ratio was 
8 to 1 in favor of the non application of fair value for both two types of organization of surveyed companies. In the next period, the situation improved and the ratio is 6 to 4 in favor of the non application of fair value for both of the two types of surveyed companies. Period (1975-1985) is very similar to the first interval of observation (19551965), only the number of tractors fair valued in the business records of legal entities is larger. In the last two observation interval ie in (1985-1995) and interval (19952005), there is an increase in the number of tractors that are fair valued in the bussiness books. The percentage of fair valued tractors is about $65 \%$ in period (1985-1995), that in the last interval all of 51 tractors were fair valued, which makes $100 \%$ of the fair value within the last observation interval. Thus, we can conclude that there is a drastic increase in the fair value compared to the previous observed 2017 year, especially in the last interval of observation. In addition, the positive thing is that the youngest tractors are fair valued, although it should be noted that this is economically speaking the old working machines, which have a value, ie after the assessment it is necessary to make a fair evaluation in business books.

The fourth point relates to the display of the authors' obtained results using Chi-square test with the aim to display a statistically significant relationship between the forms of organization, ie joint stock companies and farms and to apply fair value in business books, as well as between the age of tractors and implementing fair value in 2017 and 2018. The results presents in Table 4 clearly indicate that the resulting value is $\mathrm{p}<0.05$, which means that the authors confidently claim that the test connection is statistically significant and hypothesis 1 is rejected in favors of hypothesis 2 . It is thus confirmed that there is a statistically significant relationship between the form of ownership of agricultural enterprise and presentation of fair valuation in financial records.

Another test was performed within this point. Cochran's Q test was used to examine the existence of differences in the proportion of the sample of agricultural enterprises applying the fair valuation principle in operations in all time points (years). In addition to that, a more careful observation was conducted in order to detect differences in the implementation of fair valuation in joint-stock companies and farms even in one year.

The results presented in Table 6 show $\mathrm{p}<0.05$, which indicates the rejection of hypothesis 3 , in other words there is essentially no difference in the proportion of the sample of agricultural enterprises applying the fair valuation principle in their operations in all time points (years under observation). By rejecting hypothesis 3 , the validity of hypothesis 4 is confirmed. Therefore, there is a difference even in one point (year under observation) with regard to fair valuation in joint-stock companies and farm estates.

\section{Conclusion}

Firsly it can be concluded that the farms made great progress in relation to insurance companies regarding the practical application of the fair value of the tractors. However, it is not enough because the agricultural holdings in the application of the fair value of tractors is still lagging behind by about $1 / 3$ compared to joint stock companies. At 
the beginning of the observation period (2015) in both forms of earning a percentage of those who introduced the fair value was approximately $3 \%$ that in mid 2018 the percentage was about $37 \%$, which represents an increase of more than 10 times. The authors point to the importance of economic analyzes, with the aim of changing the functional management of the company, which is the conceptual to the real financial reporting indicated. In a word, there is progress in the adoption of the fair value of tractors in the business books of both observed economic activities in agriculture Repulbike Serbia, which are much more distinguished economic factors. However it should be noted the existence of a bad starting position in both forms of legal entities when it came to the fair value of tractors in the business books at the beginning of the observation period covered by this work.

The second conclusion would be that in 2017 both forms of organizations are not fair valued tractors that were produced in the period 1995-2005, although those are the youngest tractors by age in this study. In this interval, there were 51 tractors and their value was not fair valued in the business books. Such behavior is not in accordance with the adopted international accounting standards, and about the importance of the practical application many speak like Greuning (2006) with which also agree the authors of the work and emphasize that the future task of top management is the introduction of strict application of fair evaluation in regular operations.

The third conclusion is that in 2018 the situation changed drastically in both forms of organization in terms of fair value of the tractors. The tractors produced in the period 1995-2005 were evaluated in the business books in general.

The fourth conclusion is a statistically significant relationship between the forms of organization, and implementing fair value in the business books, as well as the existence of links between ages of tractors and application of fair value, for 2017 and 2018. The results of Chi-square test show $\mathrm{p}<0.05$, which additionally supports the view of the authors.

Beside the stated principal view, the authors point out the existence of another segment in drawing conclusions within the conclusion four. That is the existence of differences in the implementation of fair valuation of agricultural equipment, i.e. tractors, in jointstock companies and farm estates even in one year under observation. That view was confirmed by the Cochran's $\mathrm{Q}$ test, with $\mathrm{p}<0.05$.

The research was conducted in a country which in on the way to EU integration. However, even so, this research may be applied in developed countries as well, such as the EU countries. The results of the study were obtained on the basis of examples of fair valuation of agricultural equipment up to fifty years old, which even after so much time after it was made and used had its value. The existence of actual value should be treated in an appropriate way in financial records of agricultural enterprises irrespective of whether it is about a country on the way to the EU or a developed country in EU. A continuation of the research relating to valuation of agricultural equipment would be desirable against a comparison with the equipment valuation results obtained in developed countries. Any future research would be made in order to give assurance of 
a universal type of fair valuation of equipment in the course of enterprise operations. The authors with this study justify presentation of the obtained results, whereas the conclusions may serve as guidelines for management in a great number of enterprises, primarily in agriculture.

\section{Conflict of interests}

The authors declare no conflict of interest.

\section{References}

1. Anwar, S. \& Sun, S. (2015): Taxation of labour income and the skilled-unskilled wage inequality. Economic Modelling, 47: 18-22 https://doi.org/10.1016/j. econmod.2014.12.037

2. Arena, M., Arnaboldi, M., Azzone, G. (2006): Internal audit in Italian Organizations: a Multiple Case Study. Managerial Auditing Journal. 21(3): 275292. DOI: $10.1108 / 02686900610653017$

3. Arena, M., \& Azzone, G. (2007): Internal Audit Departments: Adoption and Characteristics in Italian Companies. International Journal of Auditing. 11(2): 91-114. https://doi.org/10,1111/j1099-1123.2007.00357.x

4. Argilés, J., \& Slof, E. (2001): New opportunities for farm accounting. European Accounting Review. 10: 361-383. 27. https://www.researchgate.net/ publication $/ 281239788$

5. Bagdonavicius, V. \& Nikulin, M. (2011): Chi-squared goodness-of-fit test for right censored data. International Journal of Applied Mathematics and Statistics ${ }^{\mathrm{TM}}$ 24(SI-11A): 30-50. http://www.ceser.in/ceserp/index.php/ijamas/article/view/627

6. Barker, R. \& McGeachin, A. (2013): Why is there inconsistency in accounting for liabilities in IFRS? An analysis of recognition, measurement, estimation and conservatism. Accounting and Business Research. 43(6): 579-604. https://doi.org $\underline{10.1080 / 00014788.2013 .834811}$

7. Baráth, L. \& Fertö, I. (2017): Productivity and Convergence in European Agriculture. Journal of Agricultural Economics, 68: 228-248 https://doi. org/10.1111/1477-9552.12157

8. Barlev, B. \& Haddad, J. (2003): Fair value accounting and the management of the firm. Critical Perspectives on Accounting. 14: 383-415. DOI: 10.1016/S10452354(02)00139-9

9. Boukalova, K., Kolarova, A. \& Lostak, M. (2016): Tracing shift in Czech rural development paradigm (Reflections of Local Action Groups in the media). Agricultural Economics (Zemédělská ekonomika), 62: 149-159 https://doi. org/10.17221/102/2015-AGRICECON 
10. Bozzolan, S., Laghi, E. \& Mattei, M. (2016): Amendments to the IAS 41 and IAS 16 - implications for accounting of bearer plants. Agric. Econ. - Czech. 62: 160166. https://doi.org/10.17221/48/2015-AGRICECON

11. Bratten, B. - Jennings, R. - Schwab, C. (2016): The accuracy of disclosures for complex estimates: Evidence from reported stock option fair values. Accounting, Organizations and Society. 52: 32-49. https://doi.org/10.1016/j.aos.2015.09.001

12. Brousseau, C., Gendron, M., Belanger, P. \& Coupland, J. (2014): Does fair value accounting contribute to market price volatility? An experimental approach. Accounting \& Finance. 54(4): 1033-1061. https://doi.org/10.1111/acfi.12030

13. Brown, P. - Szimayer, A. (2008): Valuing executive stock options: performance hurdles, early exercise and stochastic volatility. Accounting \& Finance. 48(3): 363-389. DOI: 10.1111/j.1467-629X.2008.00259.x

14. Cai, F. \& Wong, H. (2010): The effect of IFRS adoption on global market integration. International Business \& Economics Research Journal. 9(10): 2534. https://www.researchgate.net/publication/296622836

15. Cantino, V. (2009). Corporate governance, performance measurement and regulatory compliance of the internal control system. DataStatus, Belgrade. [in Serbian: Cantino, V. (2009). Korporativno uptravjanje, merenje performansi $i$ normativna usaglašenost sistema internih kontrola. DataStatus, Beograd].

16. Catuogno, S. - Arena, C. - Saggese, S. - Sarto, F. (2016): The Influence of Blockholders, Bondholders and Families on the Venturers' Accounting Behavior. International Journal of Business and Management. 11(8): 31-43. https://www. researchgate.net/publication/305487345

17. Christensen, B. - Glover, S. - Wood, D. (2012): Extreme Estimation Uncertainty in Fair Value Estimates: Implications for Audit Assurance. AUDITING: A Journal of Practice \& Theory. 31(1): 127-146. https://aaapubs.org/doi/abs/10.2308/ajpt10191? journalCode=ajpt

18. Daske, H. - Hail, L. - Leuz, C. - Verdi, R. (2008): Mandatory IFRS Reporting Around the World:Early evidence on the economic consequences. Journal of Accounting Research. 46: 1085-1142. http://ssrn.com/abstract=1024240

19. Dax, T. \& Oedl-Wieser, T. (2016): Rural innovation activities as a means for changing development perspectives An assessment of more than two decades of promoting LEADER initiatives across the European Union. Studies in Agricultural Economics, 118, 30-37 https://doi.org/10.7896/j.1535

20. Durocher, S. - Gendron, Y. (2014): Epistemic commitment and cognitive disunity toward fair-value accounting. Accounting and Business Research. 44(6): 630655. https://doi.org/10.1080/00014788.2014.938012 
21. Gaetano, S. \& Lamonaca, E. (2019): On the drivers of global grain price volatility: an empirical investigation. Agric. Econ. - Czech, 65: 31-42 https://doi. org/10.17221/76/2018-AGRICECON

22. Guthrie, K. - Irving, J. - Sokolowsky, J. (2011): Accounting Choice and the Fair Value Option. Accounting Horizons. 25(3): 487-510. https://doi.org/10.2308/ acch-50006

23. Endaya, K. - Hanefah, M. (2013): Internal Audit Effectiveness: An Approach Proposition to Develop the Theoretical Framework. Research Journal of Finance and Accounting. 4(10): 92-102. https://www.researchgate.net/ publication/328095795

24. Feleagă, L. - Feleagă, N. - Răileanu, V. (2012): Theoretical considerations about implementation of IAS 41 in Romania. Theoretical and Applied Economics. 2: 31-38. http://store.ectap.ro/articole/686.pdf

25. Florou, A. - Kosi, U. - Popoe, P. (2016): Are international accounting standards more credit relevant than domestic standards?. Accounting and Business Research. 46(7): 1-29. https://doi.org/10.1080/00014788.2016.1224968

26. Funnell, W. - Wade, M. - R. Jupe. (2016): Stakeholder perceptions of performance audit credibility. Accounting and Business Research. 46(6): 601-619. https://doi. org/10.1080/00014788.2016.1157680

27. Greuning, H. (2006). International Financial Reporting Standards, Practical guide. MATE, Zagreb. [in Serbian: Greuning, H. (2006). Međunarodni standardi finansijskog izveštavanja, Praktični vodič. MATE, Zagreb].

28. Kijek, A., Kijek, T., Nowak A. \& Skrzypek, A. (2019): Productivity and its convergence in agriculture in new and old European Union member states. Agric. Econ. - Czech, 65: 01-09 https://doi.org/10.17221/262/2017-AGRICECON

29. Kuo, K., Lee, C. \& Wu, S. (2018): environmental policy and labour market imperfection. Bulletin of Economic Research, 70: 175-184 https://doi.org/10.1111/ boer. 12122

30. Lee, J. (2019): Regional heterogeneity among non-operating earnings quality, stock returns, and firm value in biotech industry. Agric. Econ. - Czech, 65: 10-20 https://doi.org/10.17221/24/2018-AGRICECON

31. Novaković, S., Vukasović, D., Laban, B.,Ivić, M., Popović, V. \& Popović, S. (2018). Managing agricultural company by using internal control and significance of risk presentation, Economics of Agriculture, 2: 801-812. doi:10.5937/ekoPolj1802801N

32. Nowak, A., Janulewicz, P., Krukowski, A. \& Bujanowicz-Haraś, B. (2016): Diversification of the level of agricultural development in the member states of the European Union. Cahiers Agricultures, 25: 55004 https://doi.org/10.1051/ cagri/2016040 
33. Popović, S. (2014). Socio-economic factors limiting the development of agrarian, Feljton, Novi Sad. [in Serbian: Popović, S. (2014). Socio-ekonomski faktori ograničenja razvoja agrara, Feljton, Novi Sad].

34. Popović, S., Mijić, R. \& Grublješić, Ž. (2014a): Internal control and internal audit in the function of management, Škola Biznisa, 1, 95-107. [in Serbian: Popović, S., Mijić, R. i Grublješić, Ž. (2014a): Interna kontrola i interna revizija u funkciji menadžmenta, Škola Biznisa, 1, 95-107].

35. Popović, S., Majstorović, A. and Grublješić Ž. (2015). Valuation of facilities in use and application of international accounting standards, Actual problems of economics, 3(165): 379-387. https://eco-science.net/en/downloads

36. Popović, S., Đuranović, D., Laban, B., Ivić, M., Jovin, S., Nastić, S., Grublješić, Ž. \& Popović, V. (2018). Impact of different light intensity on the production of the plant narcissus 1. and its financial effects, Economics of Agriculture, 4: 13591370. doi:10.5937/ekoPolj1804359P

37. Rodriguez, M., Miguel, Sanchez, L., Cejudo, E. \& Antonio, C. (2019): Variety in local development strategies and employment: LEADER programme in Andalusia. Agric. Econ. - Czech, 65: 43-50 https://doi.org/10.17221/106/2018AGRICECON

38. Soltani, B. (2009). Audit, International Approach, Mate, Zagreb. [in Serbian: Soltani, B. (2009). Revizija, Međunarodni pristup, Mate, Zagreb].

39. Smith, J., \& Weeks, J. (2018). Bringing democratic choice to Europe's economic governance: the EU treaty changes we need, and why we need them. Journal of Self-Governance \& Management Economics, 6(3)

40. Turjačanin, V. \& Čekrlija, Đ. (2006). Basic statistical methods and techniques in SPSS-U. Centar za kulturni i socijalni popravak, Banja Luka [in Serbian: Turjačanin, V. i Čekrlija, Đ. (2006). Osnovne statističke metode i tehnike u $S P S S-U$, Centar za kulturni i socijalni popravak, Banja Luka].

41. Wang, D. (2019): Manufacturing and agricultural pollution, private mitigation and wage inequality in the presence of pollution externalities. Agric. Econ. Czech, 65: 51-58 https://doi.org/10.17221/79/2018-AGRICECON

42. Williams, C. (2010). Principles of management, DataStatus, Belgrade. [in Sebian: Williams, C. (2010). Principi menadžmenta, DataStatus, Beograd]. 